\title{
The Social and Policy Context of Curing Syphilis: Commentary on Francis (2013)
}

\author{
Joseph D. Tucker
}

Published online: 16 July 2013

(C) Springer Science+Business Media New York 2013

The article by Francis (2013) suggesting that the development of a new syphilis cure (penicillin) contributed to increasingly unsafe sexual behaviors raises several interesting questions, especially in light of the fact that curing HIV is now a strategic priority of both the International AIDS Society and the National Institutes of Health. Investigating how new sexually transmitted infection (STI) cures may have unintended consequences requires a careful analysis of previous STIs such as syphilis. However, Francis' study had two shortcomings. First, Francis' argument about a decreasing "cost of syphilis" ignored the persistent stigma associated with syphilis in the post-penicillin era. The study under-emphasized the moral and social context of syphilis. Stigma associated with syphilis remains a powerful social force with direct public health implications (Lichtenstein, 2003; Tucker \& Tuminez, 2011). Second, Francis misconstrued the potential role of deteriorating VD control and prevention systems in understanding subsequent behavioral changes.

The early 1950s saw massive cuts in U.S. VD curative and behavioral funds (Green, Talbot, \& Morton, 2001). Federal VD funds shrank from over 17 million dollars in 1949 to 3 million dollars in 1955 (Anderson, 1965). Prematurely decreasing funds for behavioral prevention likely played some role in subsequent behavioral changes. Penicillin did indeed represent a transformative watershed moment in controlling syphilis, but this moment must be interpreted within the social and institutional context of the period. As HIV cures move from the bench to the clinic
(Hutter et al., 2009; Persaud et al., 2013; Saez-Cirion et al., 2013), consideration of unintended consequences on individual behaviors and population-based control programs will be critical.

\section{References}

Anderson, O. W. (1965). Syphilis and society: Problems of control in the United States, 1912-1964. Chicago: University of Chicago Press.

Francis, A. M. (2013). The wages of sin: How the discovery of penicillin reshaped modern sexuality. Archives of Sexual Behavior, 42, 5-13.

Green, T., Talbot, M. D., \& Morton, R. S. (2001). The control of syphilis, a contemporary problem: A historical perspective. Sexually Transmitted Infections, 77, 214-217.

Hutter, G., Nowak, D., Mossner, M., Ganepola, S., Mussig, A., Allers, K., et al. (2009). Long-term control of HIV by CCR5 Delta32/Delta32 stem-cell transplantation. New England Journal of Medicine, 360, 692-698.

Lichtenstein, B. (2003). Stigma as a barrier to treatment of sexually transmitted infection in the American deep South: Issues of race, gender, and poverty. Social Science and Medicine, 57, 2435-2445.

Persaud, D., Gay, H., Ziemniak, C., Chen, Y.H., Piatak, T. W. C., Strain, M., ... Luzuriaga, K. (2013). Functional cure after very early ART of an infected infant. Paper presented at the Conference on Retroviruses and Opportunistic Infections, Atlanta, GA.

Saez-Cirion, A., Bacchus, C., Hocqueloux, L., Avettand-Fenoel, V., Girault, I., Lecuroux, C., ... ANRS Visconti Study Group. (2013). Posttreatment HIV-1 controllers with a long-term virological remission after the interruption of early initiated antiretroviral therapy ANRS VISCONTI Study. PLoS Pathogens, 9, e1003211.

Tucker, J. D., \& Tuminez, A. S. (2011). Reframing the interpretation of sex worker health: A behavioral-structural approach. Journal of Infectious Diseases (Suppl. 5), S1206-1210.
J. D. Tucker $(\bowtie)$

University of North Carolina Project-China, Number 2 Lujing

Road, Guangzhou 510095, China

e-mail: jdtucker@med.unc.edu 